\title{
Allogeneic administration of human umbilical cord-derived mesenchymal stem/ stromal cells for bronchopulmonary dysplasia: preliminary outcomes in four Vietnamese infants
}

Liem Thanh Nguyen ${ }^{1 \dagger}$, Thai T. H. Trieu ${ }^{2 \dagger}$, Hue T. H. Bui ${ }^{3 \dagger}$, Van T. Hoang ${ }^{4}$, Anh T. T. Nguyen ${ }^{3}$, Nhung T. H. Trinh ${ }^{3}$, Kien T. Nguyen ${ }^{1}$ and Duc M. Hoang ${ }^{1,4^{*}+}$

\begin{abstract}
Background: Bronchopulmonary dysplasia (BPD) is a severe condition in premature infants that compromises lung function and necessitates oxygen support. Despite major improvements in perinatal care minimizing the devastating effects, BPD remains the most frequent complication of extreme preterm birth. Our study reports the safety of the allogeneic administration of umbilical cord-derived mesenchymal stem/stromal cells (allo-UC-MSCs) and the progression of lung development in four infants with established BPD.

Methods: UC tissue was collected from a healthy donor, followed by propagation at the Stem Cell Core Facility at Vinmec Research Institute of Stem Cell and Gene Technology. UC-MSC culture was conducted under xeno- and serum-free conditions. Four patients with established BPD were enrolled in this study between May 25, 2018, and December 31, 2018. All four patients received two intravenous doses of allo-UC-MSCs (1 million cells/kg patient body weight (PBW) per dose) with an intervening interval of 7 days. Safety and patient conditions were evaluated during hospitalization and at 7 days and 1,6 and 12 months postdischarge.

Results: No intervention-associated severe adverse events or prespecified adverse events were observed in the four patients throughout the study period. At the time of this report, all patients had recovered from BPD and were weaned off of oxygen support. Chest X-rays and CT scans confirmed the progressive reductions in fibrosis.
\end{abstract}

Conclusions: Allo-UC-MSC administration is safe in preterm infants with established BPD.

Trial registration This preliminary study was approved by the Vinmec International Hospital Ethics Board (approval number: 88/2019/QĐ-VMEC; retrospectively registered March 12, 2019).

Keywords: Bronchopulmonary dysplasia, Umbilical cord tissue, Allogeneic mesenchymal stem cell administration

*Correspondence: v.duchm3@vinmec.com

${ }^{\dagger}$ Nguyen L.T, Thai T.H. Trieu, Hue T.H. Bui and Duc M. Hoang contributed equally to the work.

${ }^{1}$ Vinmec Research Institute of Stem Cell and Gene Technology, Vinmec Healthcare System, Hanoi, Vietnam

Full list of author information is available at the end of the article

\section{Background}

First discovered in 1967, bronchopulmonary dysplasia (BPD) has since emerged as the most prevalent chronic lung disorder in premature infants, resulting in reductions in alveolarization, vascular growth and overall lung function [1]. According to the National Institute of

c) The Author(s) 2020. This article is licensed under a Creative Commons Attribution 4.0 International License, which permits use, sharing, adaptation, distribution and reproduction in any medium or format, as long as you give appropriate credit to the original author(s) and the source, provide a link to the Creative Commons licence, and indicate if changes were made. The images or other third party material in this article are included in the article's Creative Commons licence, unless indicated otherwise in a credit line to the material. If material is not included in the article's Creative Commons licence and your intended use is not permitted by statutory regulation or exceeds the permitted use, you will need to obtain permission directly from the copyright holder. To view a copy of this licence, visit http://creativeco mmons.org/licenses/by/4.0/. The Creative Commons Public Domain Dedication waiver (http://creativecommons.org/publicdomain/ zero/1.0/) applies to the data made available in this article, unless otherwise stated in a credit line to the data. 
Child Health and Human Development (NICHD), BPD is defined as a persistent parenchymal lung disease in preterm infants $(<32$ weeks gestational age) with radiographic confirmation, and at 36 weeks postmenstrual age, BPD requires oxygen support for more than 3 consecutive days to maintain arterial oxygen saturation in the $90-95 \%$ range [2]. The pathological hallmarks of BPD involve disruption of lung development, impaired alveolarization and interstitial fibrosis due to antenatal (intrauterine growth restriction, maternal smoking) and/ or postnatal risk factors (mechanical ventilation, oxygen toxicity, and infection) [3, 4]. BPD commonly occurs in preterm infants who weigh less than $1000 \mathrm{~g}$, are born at 24-26 weeks of gestation and require prolonged mechanical ventilation and oxygen support [5]. Infants at less than 30 weeks gestational age are at a particularly high risk for immature respiratory system development and suffer from detrimental long-term outcomes, including high morbidity and mortality rates. In the last 50 years, advances in neonatal medicine, including the discovery of neonatal steroid treatments, which were proven to be associated with glucocorticoid-related brain injury as major side effect [6-8], surfactants [9-11], gentle ventilation treatments $[12,13]$, and effective noninvasive ventilation devices, have significantly improved the clinical outcomes in premature newborns with BPD. However, the rates of complications and mortality are still high among infants with BPD [14].

Recently, MSC therapy was used to treat BPD in an animal model. Proof-of-concept experiments in neonatal BPD rodent models demonstrated that the injection of bone marrow mesenchymal stem cells (BM-MSCs) via either the intravenous (IV) or intratracheal route had lung-protective functions, including reducing lung inflammation and pulmonary hypertension and reforming the alveolar structure, subsequently improving the survival rate [15-18]. Furthermore, a single dose of human UC-MSCs administered intratracheally prevented and rescued neonatal rats from hyperoxia-induced lung damage [19]. In humans, Ahn and colleagues conducted the first phase I clinical trial using umbilical cord bloodderived MSC (UCB-MSC) administration to prevent the manifestation of BPD in premature infants in 2014. Their results confirmed that UCB-MSC administration was safe in premature infants at risk of BPD development [20]. In 2017, our group reported the first patient with established BPD treated successfully with autologous bone marrow mononuclear cells [21]. However, obtaining bone marrow from established BPD newborns in critical condition is challenging and carries a major risk of pulmonary complications. Therefore, this study was performed to evaluate the safety of allogeneic administration of UC-MSCs based on their immunoprivilege features and eliminate the need for bone marrow aspiration in infants with established BPD. We hypothesized that allo-UC-MSC administration is safe for established BPD infants.

\section{Methods \\ Ethics}

This study was approved by the Scientific and Ethics Committee of Vinmec International Hospital (approval number: 88/2019/QĐ-VMEC). Written consent was obtained from both the umbilical cord donor and the patients' parents.

\section{Donor screening criteria for UC tissue}

Healthy women with an uncomplicated, at term pregnancy underwent serological testing, including tests for HIV, cytomegalovirus (CMV), Epstein-Barr virus (EBV), hepatitis A virus (HAV), hepatitis B virus (HBV), hepatitis $\mathrm{C}$ virus (HCV), syphilis, and chlamydia, at 38 weeks of pregnancy. The umbilical cord tissues were collected at delivery and transferred to the laboratory for further processing. A single UC sample was selected for isolation of therapeutic MSCs.

\section{Allo-UC-MSC preparation}

A single eligible UC sample was chosen for processing at the Stem Cell Core Facility at the Vinmec Research Institute of Stem Cell and Gene Technology under ISO 14644-1 (certification number: CR61119-1). Culture reagents were purchased from Thermo Fisher Scientific (https://www.thermofisher.com/) and Pan Biotech (serum-free PowerStem MSC1 culture media, P04$77355 \mathrm{~K}$, hereafter called MSC culture media) unless stated otherwise. hUC-MSC cultures were conducted under xeno- and serum-free conditions at $37{ }^{\circ} \mathrm{C}$ in a humidified incubator containing $5 \% \mathrm{CO}_{2}$. The medium was changed every 3 days until the culture reached $80 \%$ confluence, followed by passaging using CTS $^{\mathrm{TM}} \operatorname{TrypLE}^{\mathrm{TM}}$ Select (A1285901). UC-MSCs were cryopreserved at passage (P) 3 in the serum- and xeno-free defined reagent CryoStor $^{\circledR}$ CS10 (Stem Cell Technology, Canada) in liquid nitrogen (gas phase) in an automated Brooks System (Brooks Life Science, USA) for long-term storage.

To prepare UC-MSCs for therapy, aliquots of hUCMSCs at P3 were thawed in CTS ${ }^{\mathrm{TM}}$ CELLstart $^{\mathrm{TM}}$ substratecoated flasks and cultured using TryPLE passaging; under these conditions, hUC-MSCs were routinely passaged by incubation with $1 \mathrm{X}$ CTS $^{\mathrm{TM}} \operatorname{TrypLE}^{\mathrm{TM}}$ Select for $4 \mathrm{~min}$ at $37{ }^{\circ} \mathrm{C}$ to liberate single cells or, preferably, small clumps of cells and subcultured for further expansion at a seeding density of 5000 cells $/ \mathrm{cm}^{2}$. At P5, the cells were harvested using TryPLE as described above if no bacteria, fungi, mycoplasma, or endotoxins were detected and 
suspended in $10 \mathrm{ml}$ of $\mathrm{NaCl} 0.9 \%$ (Braun, USA) at a final dose of $1 \times 10^{6}$ cells/kg patient body weight (PBW) prior to delivery to the administration ward.

\section{Product release criteria}

To generate and release the final product, hUC-MSCs at P5 were freshly harvested and subjected to a quality control process including (1) cell enumeration, (2) cell viability measurement (>85\%), (3) hMSC marker analysis by a Navios flow cytometer system (Beckman Counter) using a human BD Mesenchymal Stem Kit (562,245, BD Biosciences), (4) microbiological tests for sterility, (5) a test for mycoplasma, (6) determination of the endotoxin level, (7) karyotyping, (8) a CFU assay, and (9) trilineage differentiation using StemPro ${ }^{\mathrm{TM}}$ Adipogenesis (A1007001), StemPro $^{\text {TM }}$ Chondrogenesis (A1007101), and StemPro $^{\text {TM }}$ Osteogenesis Differentiation (A1007201) kits according to the manufacturers' protocols. Oil Red O, Alicante Blue, and Alizarin Red S were used to specifically stain adipocytes, chondrocytes, and osteocytes, respectively.

\section{Patient enrollment Inclusion criteria}

1. Patients diagnosed with BPD (premature infant with a gestational age less than 32 weeks and required oxygen support ( $>21 \%$ ) for at least 28 days) according to NICHD guidelines [2].

2. Infants who underwent conventional BPD treatment (including neonatal steroid treatments, surfactants, and gentle ventilation support) without conditional improvement and remained dependent on oxygen support $\left(\mathrm{FiO}_{2}>21 \%\right)$.

3. Infants aged between 0 and 1 years old.

\section{Exclusion criteria}

1. Patients with complex heart abnormalities, congenital diaphragmatic hernia.

2. Patients with other severe conditions (active pulmonary bleeding, evidence of active infections, septic shock, unstable pulmonary hemorrhage).

\section{Mode of cell administration}

All four patients received two administrations of allo-UCMSCs at a dose of 1 million cells $/ \mathrm{kg}$ PBW via the IV route with a 7-day intervening interval. On the day of infusion, harvested cells (P5) at the targeted dose were prepared in $10 \mathrm{~mL}$ of $0.9 \% \mathrm{NaCl}$ (Braun, USA) as described above and delivered to the administration ward for IV infusion at a rate of $20 \mathrm{~mL} /$ hour.

\section{Outcome measures}

To assess safety, any major or minor adverse events during the MSCs infusion (72 h) and during the 7 days after infusion were monitored. Body temperature, blood pressure, respiratory rate, heart rate, and $\mathrm{SpO}_{2}$ were recorded regularly. All four patients were requested to attend reexamination at the hospital at 7 days, 1, 6 and 12 months after discharge. Each visit involved a full clinical assessment, including height and body weight measurements. All medications, home oxygen therapies, and rehospitalizations since the last visit were documented. $\mathrm{SpO}_{2}$ and arterial blood gas (ABG) analysis were examined at baseline and at each visit. Chest X-rays and $\mathrm{CT}$ scans were performed prior to intervention at the 6 -month (CT scan) and 12-month (chest X-ray) visits (Table 1).

\section{Statistical analysis}

The data were analyzed using one-way ANOVA with Prism GraphPad software unless otherwise stated. ANOVA was performed to compare the means of the four patients as indicated in the test. Statistical significance was defined as $\mathrm{P}<0.05$ unless otherwise indicated.

\section{Results}

\section{hUC-MSC characterization}

Our data showed that the UC-MSC line exhibited plastic adherent properties and a spindle- and fibroblast-like morphology (Fig. 1a), with a population doubling time of $24 \pm 0.6 \mathrm{~h}(\mathrm{n}=3$, mean \pm SEM). Propagation of UC-MSCs up to passage 6 introduced no karyotypical abnormalities, and the cells maintained a normal 46XY karyotype as indicated by the G-banding technique (Fig. 1b). These cells were also able to form $519 \pm 80 \mathrm{CFU} / 1000$ cells (mean \pm SEM, $n=3$ ) (Fig. 1c). Further analysis of the differentiation potential confirmed that the UC-MSC line could undergo adipogenic, chondrogenic, and osteogenic differentiation processes, illustrated by positive staining with Oil O Red, Alcian Blue, and Alizarin Red, respectively (Fig. 1d). Analysis of the expression patterns of positive markers, including CD73, CD90, and CD105, showed that more than $99 \%$ of the cells expressed all these markers, and less than $2 \%$ expressed negative markers, including CD11b, CD19, CD34, CD45, and HLR-DR (Fig. 1e). These results fulfilled the minimum criteria for MSCs proposed by the International Society for Cellular Therapy (ISCT, Table 2).

\section{Patient outcomes as a case report Patient 1}

An extremely premature girl (24 weeks and 5 days, first born of twins) was born by C-section due to premature rupture of the placental membrane with a body weight 
Table 1 General characterization of patients enrolled in the study

\begin{tabular}{|c|c|c|c|c|}
\hline Characteristics & Patient 1 & Patient 2 & Patient 3 & Patient 4 \\
\hline $\mathrm{DOB}$ & 25/05/2018 & 25/05/2018 & $01 / 08 / 2018$ & 07/07/2018 \\
\hline Gestational age at birth, weeks & 24 (+ 5 days) & 24 (+ 5 days $)$ & 34 & 28 \\
\hline Birth weight (grams) & 720 & 650 & 2400 & 1400 \\
\hline Sex & Female & Female & Male & Female \\
\hline Prenatal steroids used & Yes & Yes & No & No \\
\hline Pulmonary hypertension & Yes & Yes & No & Yes \\
\hline $\begin{array}{l}\text { Mechanical ventilation dura- } \\
\text { tion before transplantation }\end{array}$ & 3.5 months & 4.5 months & 1 month & 3 months \\
\hline $\begin{array}{l}\mathrm{PaCO}_{2} \text { level }(\mathrm{mmhg}) \text { before } \\
\text { transplantation }\end{array}$ & 37.9 & 68 & 59 & 38.6 \\
\hline $\begin{array}{l}\mathrm{HCO}_{3}-(\mathrm{mmHg}) \text { before trans- } \\
\text { plantation }\end{array}$ & 29.1 & 41.3 & 47.2 & 29.5 \\
\hline $\begin{array}{l}\text { Oxygen support before trans- } \\
\text { plantation }\end{array}$ & Nasal cannula 0.5 l/min & Nasal cannula $1.0 \mathrm{l} / \mathrm{min}$ & Nasal cannula 1.0 l/min & Nasal cannula 0.5 l/min \\
\hline $\mathrm{PaCO}_{2}$ at 6 months & 38 & 32.8 & 28.6 & 39.8 \\
\hline $\begin{array}{l}\mathrm{SpO}_{2}(\%) \mathrm{FiO}_{2}(21 \%) \text { before } \\
\text { transplantation }\end{array}$ & 75 & 91 & 70 & 91 \\
\hline $\mathrm{SpO}_{2}$ at 6 months & 100 & 95 & 99 & 97 \\
\hline $\mathrm{SpO}_{2}$ at 12 months & 100 & 100 & 100 & 97 \\
\hline $\begin{array}{l}\text { Postnatal age at UC-MSC } \\
\text { administration, days }\end{array}$ & 144 & 151 & 173 & 160 \\
\hline $\begin{array}{l}\text { Weight at UC-MSC administra- } \\
\text { tion (grams) }\end{array}$ & 3600 & 4000 & 5400 & 3800 \\
\hline $\begin{array}{l}\text { Duration from birth to dis- } \\
\text { charge (days) }\end{array}$ & 161 & 161 & 183 & 173 \\
\hline $\begin{array}{l}\text { Duration from transplanta- } \\
\text { tion to independence from } \\
\text { oxygen support }\end{array}$ & $\begin{array}{l}3 \text { days after the } 2 \text { nd transplan- } \\
\text { tation }\end{array}$ & 2 months & 2 months & $\begin{array}{l}4 \text { days after the first trans- } \\
\text { plantation }\end{array}$ \\
\hline $\begin{array}{l}\text { Chest X-ray before transplan- } \\
\text { tation }\end{array}$ & $\begin{array}{l}\text { Diffuse fibrosis, atelectasis, } \\
\text { diffuse haziness }\end{array}$ & $\begin{array}{l}\text { Diffuse fibrosis, atelec- } \\
\text { tasis, diffuse haziness }\end{array}$ & $\begin{array}{l}\text { Air trapping, diffuse fibrosis, } \\
\text { atelectasis, diffuse hazi- } \\
\text { ness }\end{array}$ & $\begin{array}{l}\text { Air trapping, diffuse fibrosis, } \\
\text { atelectasis, diffuse haziness }\end{array}$ \\
\hline $\begin{array}{l}\text { Chest X-ray } 12 \text { months after } \\
\text { transplantation }\end{array}$ & Reduction in fibrosis & Reduction in fibrosis & Normal & Normal \\
\hline
\end{tabular}

(BW) of $720 \mathrm{~g}$. Soon after birth, the patient developed signs of respiratory distress syndrome with retraction followed by apnea, cyanosis $\left(\mathrm{SpO}_{2}\right.$ ranged from 60 to $70 \%$ ) and bradycardia with a heart rate below $100 \mathrm{bpm}$. She was immediately intubated and placed on mechanical ventilation, with a peak inspiratory pressure (PIP) of $18 \mathrm{cmH}_{2} \mathrm{O}$ and a positive end-expiratory pressure (PEEP) of $5 \mathrm{cmH}_{2} \mathrm{O}$. Chest X-ray showed a stage 2 hyaline membrane requiring one dose of surfactant (Curosurf) at $200 \mathrm{mg} / \mathrm{kg} \mathrm{BW}$. Heart ultrasound detected patent ductus arteriosus (PDA), which closed after one course of paracetamol $(15 \mathrm{mg} / \mathrm{kg} / 6 \mathrm{~h})$ for seven days, and no evidence of pulmonary artery hypertension (PAH) was observed on echocardiogram after treatment. In addition, the patient suffered from septicemia caused by Staphylococcus epidermidis, resulting in necrosis at the distal phalanx of the left little and ring fingers and requiring antibiotic treatment. In the first 2 months, the patient was supported with synchronized intermittent mandatory ventilation (SIMV); the patient was then switched to continuous positive airway pressure therapy (CPAP) at $7 \mathrm{cmH}_{2} \mathrm{O}$ and $50 \% \mathrm{FiO}_{2}$ for the following 1.5 months. At 3.5 months postnatal age, the patient was diagnosed with BPD and continued to receive oxygen support via a nasal cannula at $0.5-1 \mathrm{~L} / \mathrm{min}$. Nebulized corticosteroids at 100 $\mathrm{mcg} / \mathrm{kg} 4 \mathrm{times} /$ day were administered for a 1 -month period. A combination of diuretics (furosemide at $1 \mathrm{mg} /$ $\mathrm{kg} / 12 \mathrm{~h})$, spironolactone $(2 \mathrm{mg} / \mathrm{kg} / 12 \mathrm{~h})$ and bronchodilators (inhaled $\beta 2$-agonists) together with nutrient enhancement (high-calorie nutrition and supplementation with vitamins $\mathrm{E}, \mathrm{A}, \mathrm{K})$ were initiated for 2 months. However, at 4.5 months postnatal age, the patient's BPD was not improved, with the $\mathrm{SpO}_{2}$ off oxygen support dropping to $90 \%$. The chest CT scan and X-ray at 3.5 months postnatal age confirmed the formation of diffuse fibrosis, atelectasis in the upper lobes of both lungs 


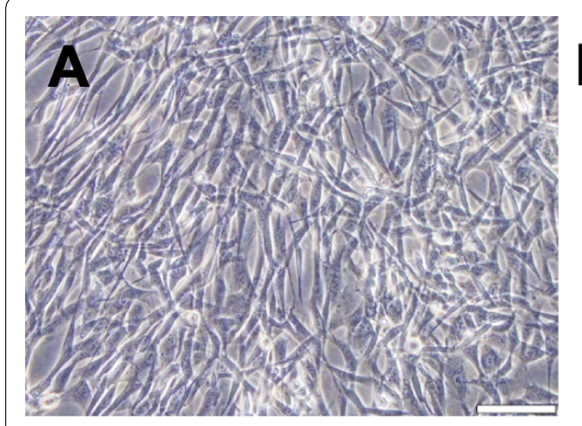

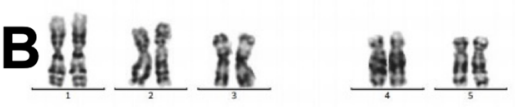

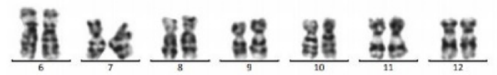
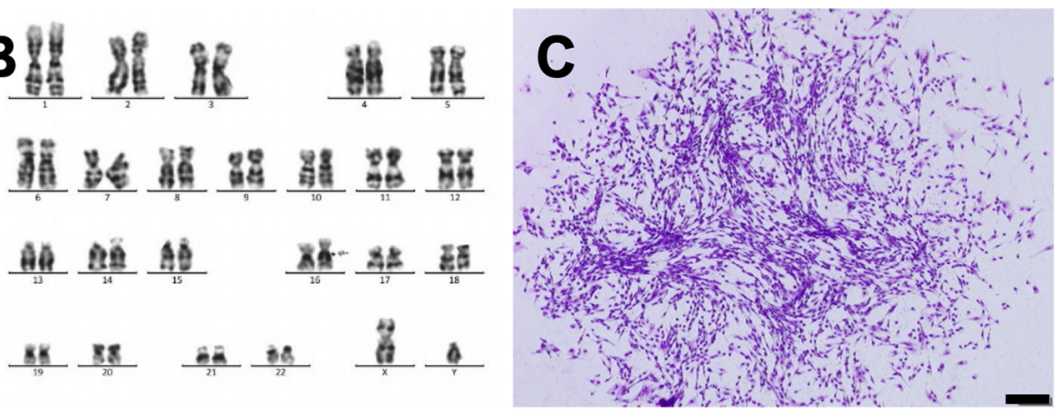

D Adipogenic

Chondrogenic
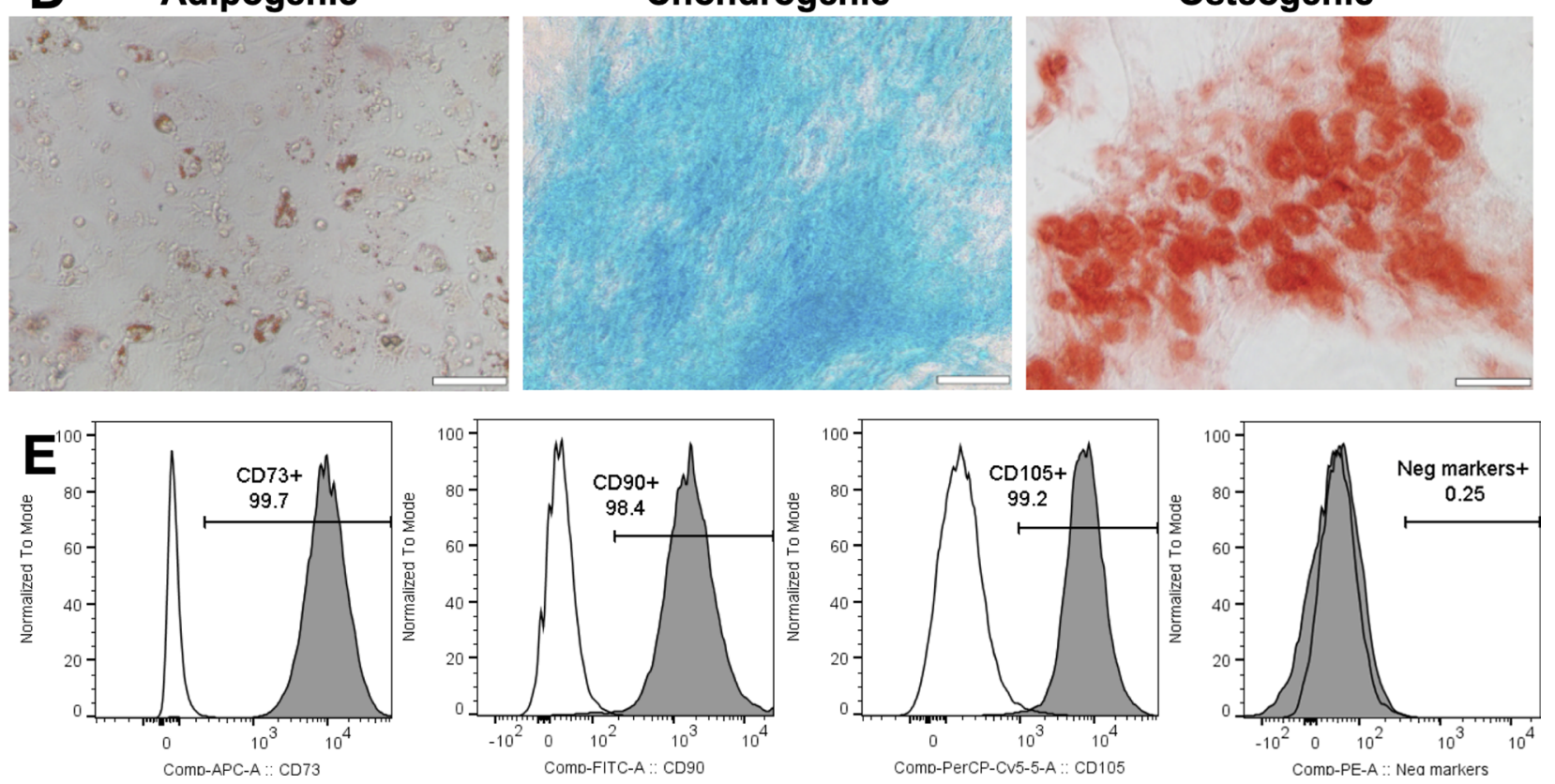

Fig. 1 Characterization of hUC-MSC sources for allogeneic administration to patients with severe BPD. a hUC-MSCs were obtained from a healthy donor after written informed consent was given. The morphology of hUC-MSCS (P3) expanded in xeno- and serum-free culture medium was spindle-shaped, and the cells were adherent, forming a monolayer in 2D culture. $\mathbf{b}$ The cells maintained a normal karyotype after 6 passages in culture in vitro, with a population doubling time of $28 \pm 1.3 \mathrm{~h}$. c The hUC-MSCs exhibited colony-forming features (140 \pm 15 CFU/1000 cells, mean $\pm S E M, n=3$ ) and $\mathbf{d}$ were able to differentiate into three lineages. e Assessment of MSC markers using flow cytometry confirmed the expression of MSC-positive markers (CD73, CD90, and CD105 > 98\%) and less than 2\% negative markers. Scale bar: $100 \mu \mathrm{m}$

and significant air trapping in both lower lobes (Figs. 2a, 3a).

Before allo-UC-MSC administration, chronic hypercapnia was confirmed by ABG analysis with the following measured values: $\mathrm{pH}$ of $7.31, \mathrm{PaCO}_{2}$ of $68 \mathrm{mmHg}$, $\mathrm{HCO}_{3}-$ of $41.3 \mathrm{mmol} / \mathrm{L}$, and $\mathrm{PaO}_{2}$ of $73 \mathrm{mmHg}$. $\mathrm{PAH}$ was determined based on a maximum pulmonary artery pressure (PAP) of $40 \mathrm{mmHg}$ and illustrated on echocardiogram, and the pro-BNP level was high $(1942 \mathrm{ng} / \mathrm{mL})$. Oral sidenafil $(1.5 \mathrm{mg} / \mathrm{kg} / 6 \mathrm{~h})$ and bosentan $(1 \mathrm{mg} / \mathrm{kg} / 8 \mathrm{~h})$ were administered when the patient was 4 months old. The allo-UC-MSC administration was performed at 144 days postnatal age (47 weeks gestational age). No signs of serious adverse events were observed during the two interventions. Three days after the second infusion, the patient could breathe spontaneously with an $\mathrm{SpO}_{2}$ of $96 \%$ without oxygen support. The patient was discharged at 161 days postnatal age (17 days postadministration).

At the first follow-up visit, the patient was alert, had a BW of $4 \mathrm{~kg}$ and was spontaneously breathing, with an $\mathrm{SpO}_{2}$ of $96 \%$ without oxygen support. Blood gas analysis revealed a reduction in the saturated $\mathrm{CO}_{2}$ in the blood as follows: $\mathrm{pH}$ of $7.5, \mathrm{PaCO}_{2}$ of $33.6 \mathrm{mmHg}, \mathrm{HCO}_{3}$ - of $26.9 \mathrm{mmol} / \mathrm{L}, \mathrm{BE}$ of $4 \mathrm{mmol} / \mathrm{l}$ and $\mathrm{PaO}_{2}$ of $46 \mathrm{mmHg}$. The pro-BNP level had dropped to $351.9 \mathrm{ng} / \mathrm{ml}$, leading to the termination of $\mathrm{PAH}$ treatment at 4 months 
Table 2 Release criteria of allo-UC-MSC administration

\begin{tabular}{|c|c|c|c|c|c|c|c|c|}
\hline \multirow[t]{2}{*}{ Transplantation } & \multicolumn{2}{|c|}{ Patient 1} & \multicolumn{2}{|c|}{ Patient 2} & \multicolumn{2}{|c|}{ Patient 3} & \multicolumn{2}{|c|}{ Patient 4} \\
\hline & $1 s t$ & 2nd & 1st & 2nd & 1st & 2nd & $1 \mathrm{st}$ & 2nd \\
\hline Cell doses $\left(\times 10^{6}\right.$ cells $\left./ \mathrm{kg}\right)$ & 1.0 & 1.0 & 1.0 & 1.0 & 1.0 & 1.0 & 1.0 & 1.0 \\
\hline Cell viability (\%) & 97 & 97 & 96 & 98 & 98 & 98 & 97 & 89 \\
\hline CD73 (\%) & 97.9 & 98.5 & 98.5 & 98.3 & 98.4 & 99.63 & 99.5 & 99.6 \\
\hline CD90 (\%) & 100 & 100 & 100 & 100 & 100 & 99.7 & 100 & 99.9 \\
\hline CD105 (\%) & 100 & 100 & 100 & 100 & 100 & 100 & 100 & 100 \\
\hline Negative markers* $(\%)$ & 0.9 & 0.3 & 0.3 & 0.7 & 0.1 & 0.1 & 0.0 & 0.0 \\
\hline Microorganism and fungal tests & \multicolumn{8}{|c|}{ Negative } \\
\hline Mycoplasma & \multicolumn{8}{|c|}{ Negative } \\
\hline Endotoxin (EU/ml) & $<0.1$ & $<0.05$ & $<0.1$ & $<0.1$ & 0.073 & $<0.05$ & $<0.05$ & $<0.05$ \\
\hline Karyotyping & \multicolumn{8}{|c|}{$46, X Y, 16 q h+$} \\
\hline CFU assay (CFU per 1000 cells) & \multicolumn{8}{|c|}{$519 \pm 80$} \\
\hline Adipogenesis & \multicolumn{8}{|c|}{ Pass } \\
\hline Chondrogenesis & \multicolumn{8}{|l|}{ Pass } \\
\hline Osteogenesis & \multicolumn{8}{|l|}{ Pass } \\
\hline
\end{tabular}

* CD11b, CD19, CD34, CD45, and HLR-DR

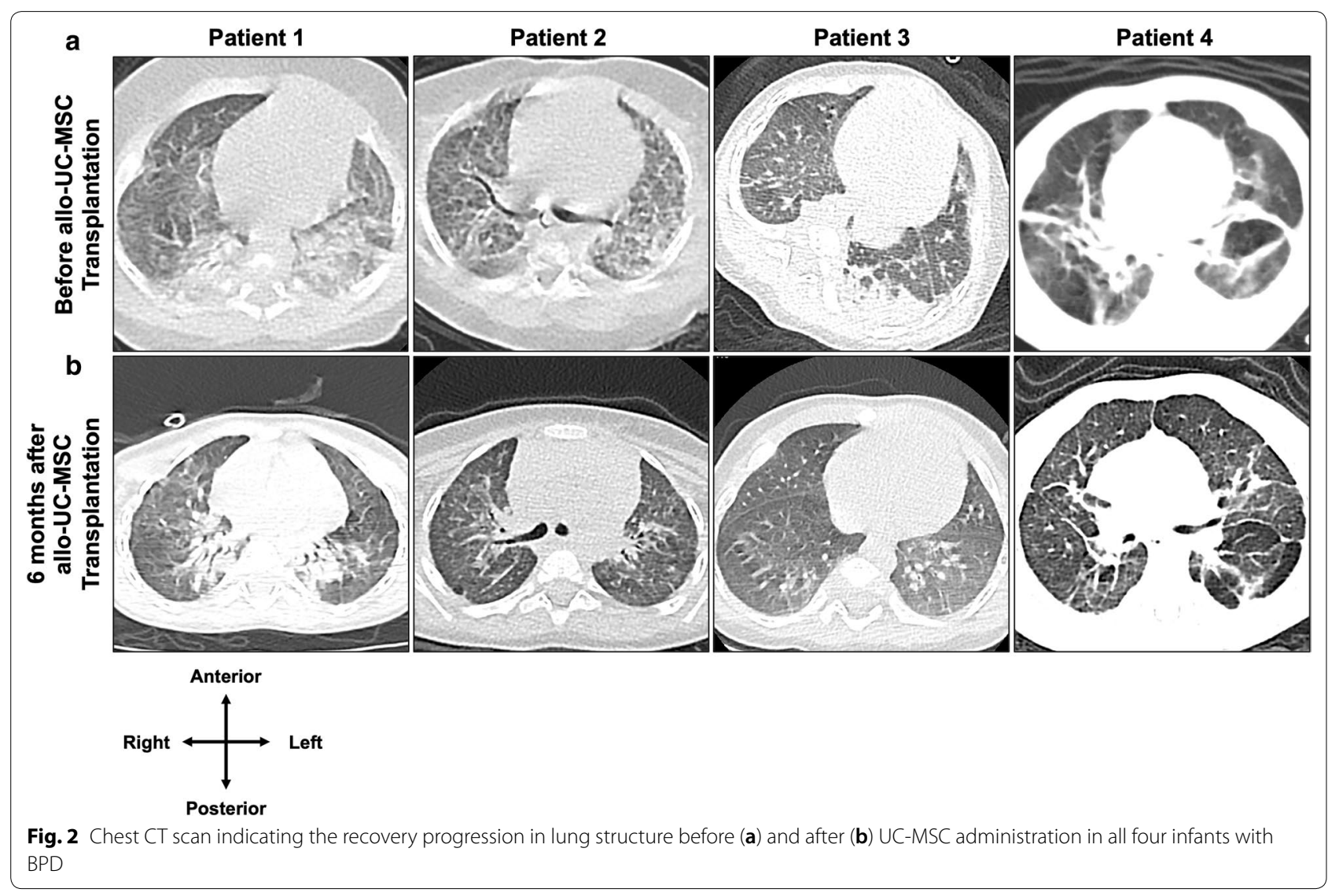

postadministration. At the 1-month follow-up examination, the patient was conscious and active, and her BW had increased to $4.3 \mathrm{~kg}$, with air fully entering both lungs. She spontaneously breathed and had an $\mathrm{SpO}_{2}$ of $97 \%$ on room air without oxygen support. The laboratory tests revealed that her $\mathrm{pH}$ (7.37), $\mathrm{PaCO}_{2}(46.3 \mathrm{mmHg})$, 

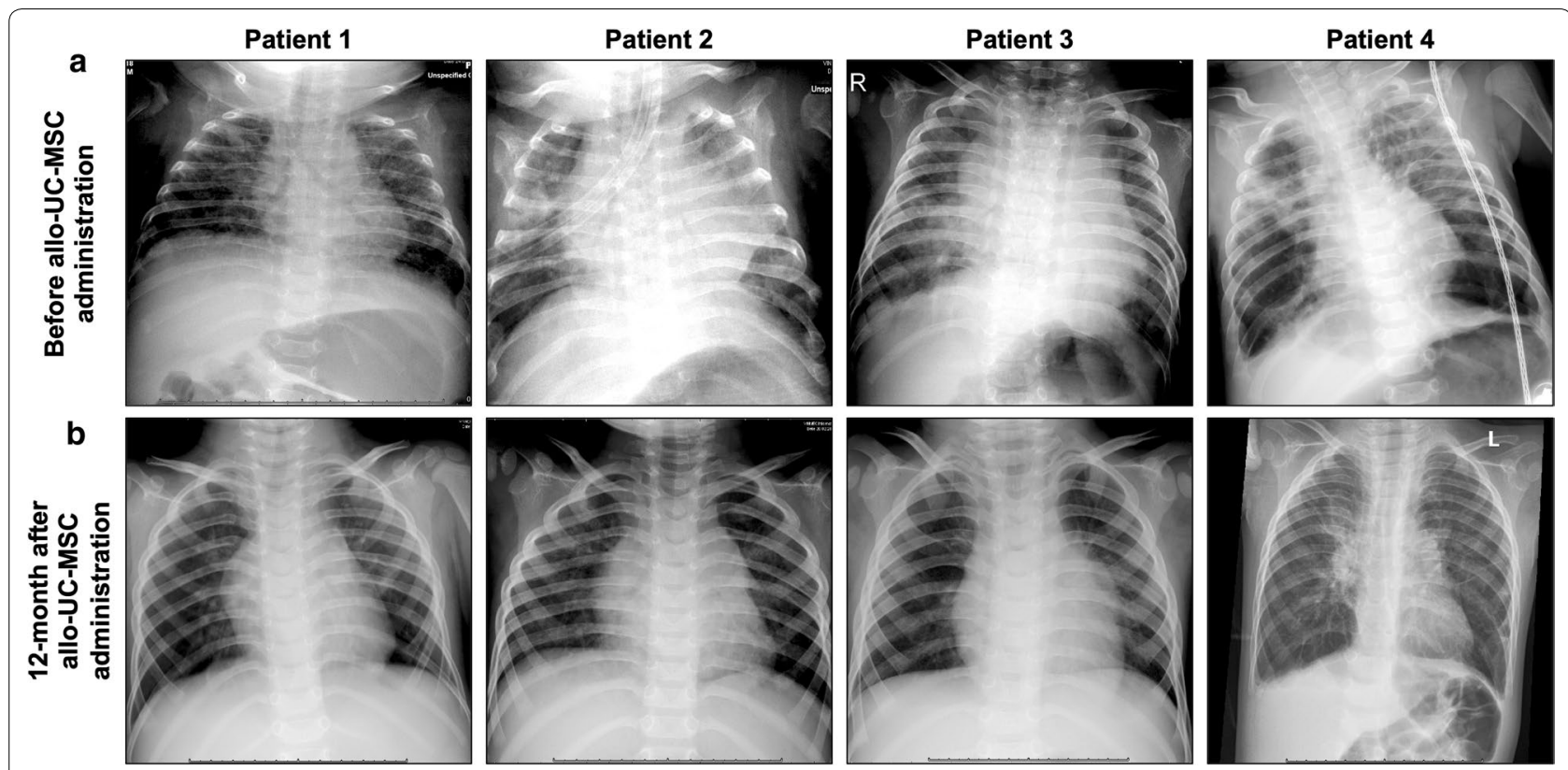

Fig. 3 Chest radiographs of the four patients enrolled in the study showing the changes in cystic fibrosis before (a) and 12 months after administration (b). The results indicate the progressive recovery of the lungs, with more air entering both lungs and a reduction in fibrosis after allo-UC-MSC administration

$\mathrm{HCO}_{3^{-}}(27 \mathrm{mmol} / \mathrm{L})$, and $\mathrm{PaO}_{2}(42 \mathrm{mmHg})$ remained stable post administration. Hematological analysis also confirmed the absence of inflammation and sepsis, as indicated by the Hgb level $(129 \mathrm{G} / \mathrm{L})$, white blood cell count (WBC, $6.1 \mathrm{G} / \mathrm{L}$ ), and neutrophil level (6.4\%). At the 6-month visit, the patient no longer required oxygen support, with her $\mathrm{SpO}_{2}$ reaching $100 \%$, and she exhibited good air entry into the lungs, no sign of dyspnea and $\mathrm{ABG}$ results in the normal ranges $\left(\mathrm{pH}: 7.37, \mathrm{PaCO}_{2}: 38 \mathrm{mmHg}\right.$, $\mathrm{HCO}_{3}-: 21.9 \mathrm{mmol} / \mathrm{L}, \mathrm{PaO}_{2}: 41 \mathrm{mmHg}$, and $\mathrm{SpO}_{2}: 100 \%$ ); the pro-BNP level was $283.1 \mathrm{ng} / \mathrm{ml}$. A reduction in lung fibrosis was observed on chest CT without PAH (Fig. 2b). At 12 months postdischarge, the patient's condition was improved. Her BW had increased to $7.5 \mathrm{~kg}$. ABG results were in the normal ranges $\left(\mathrm{pH}: 7.34, \mathrm{PaCO}_{2}: 35.5 \mathrm{mmHg}\right.$, $\mathrm{PaO}_{2}: 87 \mathrm{mmHg}, \mathrm{BE}:-6 ; \mathrm{HCO}_{3}-: 19.3 \mathrm{mmol} / \mathrm{l}$ ), and her pro-BNP level was 154.2 without PAH treatment. Lung fibrosis was reduced on chest X-ray at the 12-month visit (Fig. 3b). The detailed progression of the patient's condition is described in Additional file 1: Table S1.

\section{Patient 2}

The second premature neonate was the twin of patient 1 and was enrolled in this study with a BW of 650 g. Similar to her twin sister, the patient suffered from respiratory distress syndrome, including gasping, followed by apnea, bradycardia, and cyanosis with an $\mathrm{SpO}_{2}$ between 50 and $60 \%$. The patient was positive pressure-ventilated by a bag mask and then intubated and placed on a ventilator in SIMV mode (with ventilator parameters similar to those in the first case). Chest X-ray revealed a stage 3 hyaline membrane, and a surfactant was given at a dose of $200 \mathrm{mg} / \mathrm{kg} \mathrm{BW}$ on the 1st and 3rd days after birth. A large PDA was detected by cardiac echography, requiring one course of indomethacin $(0.2 \mathrm{mg} / \mathrm{kg} / 12 \mathrm{~h})$ within the first postnatal week as previously described [22]. After 2 months on SIMV, ventilation support was switched to CPAP with a PEEP of $6 \mathrm{cmH}_{2} \mathrm{O}$ and $40 \% \mathrm{FiO}_{2}$. After treatment, the PDA size was reduced $(1 \mathrm{~mm})$, and the shunt size was small; however, the size increased gradually and reached $3.6 \mathrm{~mm}$ at 3 months. The PDA was maintained at a large size and required surgical closure at 3.5 months of age. Although the PDA was closed without complications, $\mathrm{PAH}$ was observed $(38 \mathrm{mmHg})$, and the pro-BNP level was $2223 \mathrm{ng} / \mathrm{ml}$, leading to treatment with $1 \mathrm{mg} / \mathrm{kg} / 6 \mathrm{~h}$ sildenafil and $2 \mathrm{mg} / \mathrm{kg} / 8 \mathrm{~h}$ bosen$\tan$. After the operation, the patient was on CPAP at 6 $\mathrm{cmH}_{2} \mathrm{O}$ at an $\mathrm{FiO}_{2}$ of $30 \%$ before switching to nasal cannula oxygen at a rate of $1 \mathrm{~L} / \mathrm{min}$ after 1 month to maintain a stable $\mathrm{SpO}_{2}$ between 93 and $97 \%$. X-rays and chest $\mathrm{CT}$ scans at 4 months of age indicated diffuse fibrosis in the lung structures, with atelectasis in the upper lobes of both lungs and significant air trapping in both lower lobes (Figs. 2a and 3a). The patient was confirmed as having BPD and treated with nebulized corticosteroids (100 mcg/kg 4 times/day), diuretics (furosemide, $1 \mathrm{mg} /$ 
$\mathrm{kg} / 12 \mathrm{~h}$ ), spironolactone ( $2 \mathrm{mg} / \mathrm{kg} / 12 \mathrm{~h}$ ), bronchodilators (inhaled 32 -agonists) in combination with ipratropium bromide and other supportive measures (high-calorie nutrition, vitamins $\mathrm{E}$ and $\mathrm{A}$, etc.) for 6 weeks. However, the patient's condition did not improve, and she remained dependent on oxygen support, leading to allo-UC-MSC administration at 151 days postnatal age. Prior to intervention, $\mathrm{ABG}$ analysis revealed a $\mathrm{pH}$ of 7.6, $\mathrm{PaCO}_{2}$ of $37.9 \mathrm{mmHg}, \mathrm{PaO}_{2}$ of $35 \mathrm{mmHg}$, increased $\mathrm{HCO}_{3}-$ of $29.1 \mathrm{mmol} / \mathrm{L}$ and BE of $8 \mathrm{mmol} / \mathrm{L}$. Three days after administration, the patient was discharged with oxygen support via nasal cannula at $1 \mathrm{~L} /$ minute, a respiration rate of $64-67$ breaths/minute, and an $\mathrm{SpO}_{2}$ of $83 \%$ $\left(\mathrm{FiO}_{2}: 21 \%\right)$.

At the first follow-up visit, the patient's body weight had increased to $4.3 \mathrm{~kg}$, her heart rate was $145 \mathrm{bpm}$, and she still required oxygen support at $0.5 \mathrm{l} / \mathrm{min}$ to maintain an $\mathrm{SpO} 2$ over $92 \%$ (83\% without oxygen support). The ABG results showed a $\mathrm{PaCO}_{2}$ of $67 \mathrm{mmHg}, \mathrm{HCO}_{3}-$ of $32.3 \mathrm{mmol} / \mathrm{L}, \mathrm{PaO}_{2}$ of $36 \mathrm{mmHg}$, and $\mathrm{BE}$ of $6 \mathrm{mmol} / \mathrm{l}$. The total hemoglobin level, WBC level, and neutrophil percentage were $129,6.1 \mathrm{G} / \mathrm{L}$, and $6.4 \%$, respectively. The patient's condition had improved by her 1-month followup visit, with reductions in both herPaCO 2 and $\mathrm{HCO}_{3}-$, while her $\mathrm{SpO}_{2}$ was maintained at $94-98 \%$ on oxygen via a cannula at $0.5 \mathrm{l} / \mathrm{min}$. Two months after the first hUCMSC administration, home oxygen monitoring results confirmed that the patient could breathe normally, and her $\mathrm{SpO}_{2}$ had reached 95\% (Additional file 3: Table S3).

From the 6-month follow-up onwards, the patient's health had stabilized under normal conditions, with her $\mathrm{BW}$ reaching $8 \mathrm{~kg}$ at the 12 -month visit. All ABG tests were within normal parameters at the 6-month visit, further confirming the positive changes of the patient from BPD. Her $\mathrm{SpO}_{2}$ was maintained at $95 \%$ at the 6-month visit and reached $100 \%$ at the 12-month follow-up. Blood gas analysis at 12 months showed that all parameters were within the normal limits without oxygen support. The chest $\mathrm{CT}$ scan at the 6-month visit revealed a reduction in lung fibrosis (Fig. 2b). A normal chest X-ray was observed at the 12-month follow-up (Fig. 3b). It is important to note that the maximal PAP recorded at the 6-month visit was $46 \mathrm{mmHg}$, with a pro-BNP level of $511 \mathrm{ng} / \mathrm{ml}$, leading to the administration of sildenafil $(1 \mathrm{mg} / \mathrm{kg} / 12 \mathrm{~h})$. At the 12 -month visit, the maximum PAP was $37 \mathrm{mmHg}$, and the pro-BNP level was reduced to $202 \mathrm{ng} / \mathrm{mL}$; therefore, a lower dose of sildenafil $(0.5 \mathrm{mg} / \mathrm{kg} / 12 \mathrm{~h})$ was given. The detailed progression of the patient's condition is described in Additional file 2: Table S2.

\section{Patient 3}

A 34-week-old male infant was prematurely born due to premature rupture of the placental membrane and had a BW of $2.4 \mathrm{~kg}$ at birth. The patient was diagnosed with hyaline membrane disease and required ventilator support. After 3 consecutive treatments with a surfactant, he was successfully weaned off of mechanical ventilation at 3 months postnatal age. However, he still depended on oxygen support at a rate of $1 \mathrm{~L} / \mathrm{min}$ via a sponge cannula. The diagnosis of BPD with vocal cord scarring and laryngomalacia combined with periventricular leukomalacia was confirmed using nasopharyngoscopy, CT and MRI.

Upon admission to Vinmec International Hospital, the patient was supported with oxygen at a rate of $1 \mathrm{~L} /$ min via nasal cannula to maintain the target $\mathrm{SpO}_{2}$ above $92 \%$. The $\mathrm{SpO}_{2}$ dropped dramatically to $60 \%$ without oxygen support or crying. The patient suffered from severe chronic hypercapnia with $\mathrm{pH}, \mathrm{BE}, \mathrm{PaCO}_{2}$ and $\mathrm{HCO}_{3}-$ levels maintained at $7.35,12 \mathrm{mmol} / \mathrm{L}, 63.6 \mathrm{mmHg}$ and $67.2 \mathrm{mmol} / \mathrm{L}$, respectively, whereas his $\mathrm{SpO}_{2}$ and $\mathrm{PaO}_{2}$ were relatively low $\left(60 \%\right.$ at an $\mathrm{FiO}_{2}$ of $21 \%$ and $44 \mathrm{mmHg}$, respectively). No cardiovascular malfunction or $\mathrm{PAH}$ was detected on echocardiogram, and the pro-BNP level was $176.5 \mathrm{ng} / \mathrm{ml}$. The patient was diagnosed with CMV infection, with a viral load of $1.44 \times 10^{5}$ copies $/ \mathrm{ml}$ in the endotracheal fluid. After completion of CMV treatment with valganciclovir for 3 weeks, the chest $\mathrm{CT}$ scan and radiograph revealed lung fibrosis with significant air trapping in both lungs and lung inflammation (Figs. 2a and $3 a$ ), and the patient could not be weaned off of oxygen. He was dependent on oxygen at a rate of $1 \mathrm{~L} / \mathrm{min}$ via nasal cannula to maintain an $\mathrm{SpO}_{2}$ between $94-96 \%$.

Before administration, the patient still suffered from chronic hypercapnia with the following parameters: $\mathrm{pH}$ 7.51, $\mathrm{PaCO}_{2} 59 \mathrm{mmHg}, \mathrm{HCO}_{3}-47.2 \mathrm{mmol} / \mathrm{L}$, and $\mathrm{PaO} 2$ $57 \mathrm{mmHg}$. He required oxygen support via nasal cannula at $1 \mathrm{~L} / \mathrm{min}$ to maintain an $\mathrm{SpO}_{2}$ between 92-97\%; without oxygen support, his $\mathrm{SpO}_{2}$ was as low as $70 \%$ $\left(\mathrm{FiO}_{2}: 21 \%\right)$. The PCR results and hematological analysis (WBC: $23.9 \mathrm{G} / \mathrm{L}$, neutrophils: 20.9\%, and Hgb: $95 \mathrm{G} / \mathrm{L}$ ) confirmed that the patient no longer carried CMV; he did not suffer from inflammation, nor did he have sepsis. Allo-UC-MSC administration was performed at 173 days postnatal age with no signs of severe adverse events. The patient was discharged 13 days after the first intervention with oxygen support via nasal cannula at $0.5 \mathrm{~L} / \mathrm{min}$ with an $\mathrm{SpO}_{2}$ ranging between 93 and $98 \%$.

At the first visit, the patient's general condition was fair, and he was conscious, with his BW slightly increased to $5.3 \mathrm{~kg}$. He was still receiving oxygen at $0.5 \mathrm{l} / \mathrm{min}$ via cannula to maintain an $\mathrm{SpO}_{2}$ at $92-98 \%$. The patient's hypercapnic condition was reduced, with the following ABG test results: $\mathrm{pH}$ of $7.46, \mathrm{PaO}_{2}$ of $45 \mathrm{mmHg}, \mathrm{PaCO}_{2}$ 
of $52.6 \mathrm{mmHg}$ and $\mathrm{HCO}_{3}-$ of $38 \mathrm{mmol} / \mathrm{L}$. His $\mathrm{SpO}_{2}$ without oxygen support had increased to $85 \%$ on room air. The total blood count results remained in the normal ranges. The blood C-reactive protein (CRP) level was $0.2 \mathrm{mg} / \mathrm{L}$, confirming that the patient had not developed an inflammatory response. At the 1-month follow-up, the patient was still dependent on oxygen support at a rate of $0.5 \mathrm{~L} / \mathrm{min}$ to maintain an $\mathrm{SpO}_{2}$ level between $95 \%$ and 98. At two months postadministration, the patient was independent of active oxygen support, with an $\mathrm{SpO}_{2}$ of 96-98\%.

The clinical team observed the progression in patients' condition at the 6-month visit. The patient was conscious and was able to crawl, laugh, and actively respond to his parent's voice. Due to the complication of periventricular leukomalacia, an additional Denver II test was conducted at the 6-month examination, and the results confirmed that the patient's gross motor function was similar to that expected at 3 months, his language ability was equivalent to that expected at 5-6 months, his fine motor adaptive skills were equivalent to those expected at 3 months, and his personal-social skills were equivalent to those expected at 5 months. Moreover, improved respiratory function was also documented, with better airflow in both lungs, no crackles or rales, and no signs of retraction or nasal flaring at the 6-month visit. All ABG results remained stable at the 12-month visit, with no sign of respiratory distress syndrome, an improved saturated oxygen level $\left(\mathrm{SpO}_{2}: 100 \%\right)$ and a normal $\mathrm{CO}_{2}$ level in the blood $\left(\mathrm{pH}\right.$ of $7.4, \mathrm{PaO}_{2}$ of $72 \mathrm{mmHg}$, $\mathrm{PaCO}_{2}$ of $34.8 \mathrm{mmHg}, \mathrm{HCO}_{3}-$ of $21.5 \mathrm{mmol} / \mathrm{L} ; \mathrm{BE}$ of $-3 \mathrm{mmol} / \mathrm{l}$ ). Investigation of the patient's lungs with $\mathrm{CT}$ at the 6-month visit indicated a reduction in fibrosis and the gradual recovery of lung function. Chest X-rays at the 12-month visit further confirmed the progression (Fig. 3b). The detailed progression of the patient's condition is described in Additional file 3: Table S3.

\section{Patient 4}

A premature female infant was born at another hospital at 28 weeks gestation due to premature rupture of the placental membranes with a birth weight of $1400 \mathrm{~g}$. She rapidly developed respiratory distress syndrome and required mechanical ventilation. A single dose of surfactant was given $(100-200 \mathrm{mg} / \mathrm{kg})$ on the first day. After that, the patient was placed on CPAP for a month, followed by oxygen support at $0.5-1 \mathrm{~L} / \mathrm{min}$ until she reached 36 weeks old. Dexamethasone treatment using the Dexamethasone: A Randomized Trial (DART) protocol was advised for one week to further improve the patient's condition. The patient was successfully weaned from oxygen support and discharged at 37 weeks with an
$\mathrm{SpO}_{2}$ ranging between 93 and $95 \%$. However, 2 days postdischarge, the patient developed dyspnea with acute respiratory distress and returned to the hospital, where she stayed for the next 2 months.

The patient was referred to Vinmec Hospital at 4 months old with malnutrition (BW of $3 \mathrm{~kg}$ ). Although oxygen support was maintained at $1 \mathrm{~L} / \mathrm{min}$ via nasal cannula, her $\mathrm{SpO}_{2}$ was relatively low (80\%). Auscultation showed poor air entry into the lungs with crackles and rales. Her heart rate was high (200-220 bpm), with evident cyanosis and an $\mathrm{SpO}_{2}$ of 80 on $24 \%$ oxygen. The patient was intubated immediately and placed on a ventilator in SIMV mode (PIP at $23 \mathrm{~cm} \mathrm{H}_{2} \mathrm{O}, \mathrm{PEEP}$ at $5.5 \mathrm{~cm}$ $\mathrm{H}_{2} \mathrm{O}$, and $\mathrm{FiO}_{2}$ at $50 \%$ ). Five days after the treatment, ventilation support was switched to sponge cannula with oxygen flowing at $1 \mathrm{~L} / \mathrm{min}$. The ABG examinations revealed the following: $\mathrm{pH}$ of $7.49, \mathrm{PaCO}_{2}$ of $38.6 \mathrm{mmHg}$, $\mathrm{HCO}_{3}-$ of $29.5 \mathrm{mmol} / \mathrm{l}$, and $\mathrm{PaO}_{2}$ of $60 \mathrm{mmHg}$ with FiO2: $40 \%$. Furthermore, a complete blood count showed a low platelet count $(53 \mathrm{G} / \mathrm{L})$, while the WBC, neutrophil, and $\mathrm{Hgb}$ results were 5.8, 1.3 and $112 \mathrm{G} / \mathrm{L}$, respectively. An echocardiogram was performed when the patient was stable and showed a pressure gradient through the tricuspid valve at $28 \mathrm{mmHg}$. The pro-BNP level was $8065 \mathrm{pg} /$ $\mathrm{ml}$. Hence, the patient was treated with $0.5 \mathrm{mg} / \mathrm{kg} / 8 \mathrm{~h}$ sildenafil. The viral tests confirmed a CMV infection (460 copies $/ \mathrm{ml}$ ), which was treated with valganciclovir for 21 days. The results of a chest X-ray and CT scan indicated severe lung fibrosis and substantial air trapping in both lungs (Figs. 2a and 3a).

Two UC-MSC administrations were carried out without adverse events when the patient was 160 days old. Four days after the first administration, the patient could breathe spontaneously at 55-62 breaths/minute. On the day of discharge (a week after the second administration), the patient breathed spontaneously with an $\mathrm{SpO} 2$ of 95\% without oxygen support.

At the 7-day examination, the patient still suffered from dyspnea, with a respiration rate of 53 breaths/minutes. An increase in the $\mathrm{SpO}_{2}$ level to $95 \%$ was also recorded. The pro-BNP level was reduced to $136.7 \mathrm{ng} / \mathrm{ml}$. Hematological analysis confirmed that no sepsis or inflammatory reaction had occurred after MSC administration, with a WBC count of $9.8 \mathrm{G} / \mathrm{L}$, neutrophil percentage of $12.1 \%$, Hgb level of $112 \mathrm{G} / \mathrm{L}$ and platelet count of $61 \mathrm{G} / \mathrm{L}$. One month postdischarge, the patient was conscious and active, with a BW of $4 \mathrm{~kg}$. The $\mathrm{SpO}_{2}$ was increased to $98 \%$ without oxygen support, suggesting that the patient's respiratory function had recovered.

At the 6-month visit, respiratory distress was assessed as mild. The $\mathrm{SpO}_{2}$ had stabilized at $97 \%$. The 12 -month follow-up corroborated the conclusion that the patient had recovered from BPD, with a normal $\mathrm{SpO}_{2}$ of $97 \%, \mathrm{pH}$ 
of 7.34, $\mathrm{PaCO}_{2}$ of $39.8 \mathrm{mmHg}, \mathrm{HCO}_{3}-$ of $20.8 \mathrm{mmol} / \mathrm{l}$, $\mathrm{BE}$ of $-4 \mathrm{mmol} / \mathrm{l}$, and $\mathrm{PaO}_{2}$ of $73 \mathrm{mmHg}$. At 12 months after intervention, it is worth mentioning that the patient had recovered well with regard to both her $\mathrm{SpO}_{2}$ and $\mathrm{PaO}_{2}$ levels, which were $100 \%$ and $72 \mathrm{mmHg}$, respectively. Evaluation of the lung structure on CT scans demonstrated that the fibrotic area was reduced (Fig. 2b), while alveolation and maturation of the lung had become obvious. Further assessment of the lung structure using chest X-rays at the 12-month follow-up showed no signs of atelectasis or hyperexpansion in either lung (Fig. 3b). The detailed progression of the patient's condition is described in Additional file 4: Table S4.

\section{Discussion}

All four patients tolerated the allo-UC-MSC infusion well, and no prespecified infusion-related adverse events were recorded after either the first or second administration. Specifically, no significant changes in heart rate, mean arterial pressure, oxygen saturation or body temperature were observed in any of the four infants (Additional file 5: Figure S1). These results, together with the detailed hematological analysis reported in each case, confirmed that allo-UC-MSC administration does not trigger any complications during or $72 \mathrm{~h}$ after infusion. A previous study reported the safety outcomes of the allogeneic administration of human UCB-MSCs, in which nine preterm infants received either a single dose of $1 \times 10^{7}$ cells $/ \mathrm{kg}$ or $2 \times 10^{7}$ cells $/ \mathrm{kg}$ [23]. In another single-center, open-label phase 1 trial, Lim's group administered $1 \times 10^{6}$ human amnion epithelial cells to six preterm infants with established BPD and reported the safety profile at 2 years postadministration $[24,25]$. In these trials, as in ours, no infusion toxicity or allogeneic UC-MSC intervention-associated adverse events were recorded. These results were also supported by a preclinical study evaluating the long-term safety of the allogeneic administration of MSCs in a rodent model of BPD, which reported no adverse lung effects postadministration together with persistent recovery in respiratory function and lung condition [26].

Identifying the appropriate cell source plays an important role in the success of therapy. In our study, UCMSCs were isolated from a single healthy donor as an allogeneic source for MSC administration due to the following reasons: (1) collection of UC samples is a noninvasive process, as the $\mathrm{UC}$ is medical waste discarded at birth, eliminating the need for bone marrow aspiration from infants with established BPD; (2) their rapid proliferation capacity ( $24 \pm 0.6 \mathrm{~h}$ ); and (3) their maintenance of a normal karyotype and differentiation potential during in vitro culture. Moreover, UC-MSCs have a higher paracrine potency than adult tissue-derived MSCs [27]. Moreover, previous studies performed using human amnion epithelial cells and UCB-MSCs suggest that MSCs derived from perinatal sources might be the optimal cell source for future clinical treatments of infants with BPD [23, 24].

In terms of the transplantation route, our preliminary data demonstrate the safety profile of allo-UC-MSC administration via IV infusion in neonates with established BPD. During the follow-up period, all patients exhibited the progressive recovery in lung function and stopped being dependent on mechanical oxygen support as early as 4 days after the first administration and as late as 2 months postadministration. In preclinical studies, three main routes have been tested in the treatment of BPD: intraperitoneal (usually conducted in animal models but not translatable to the clinical setting), IV, and intranasal or intratracheal administration [28]. However, the potential effects of therapies administered via these routes are contradictory. In hypoxia-exposed mice, human UC-MSCs delivered via the intraperitoneal route showed improved lung function, while those administered the cells via the intratracheal route did not [29]. Furthermore, a systematic analysis of preclinical studies suggested that MSCs administered intravenously had better effects than those administered via the intratracheal route [30]. In contrast, local intratracheal delivery of MSCs was reported to be more effective and to better attenuate hyperoxia-induced lung damage than systemic IV administration [19]. Hence, future studies are needed to confirm the suitable administration route of MSC therapy for BPD infants.

To achieve optimal therapeutic effects, determination of the administration timing is a critical issue that remains to be solved. In our study, all four patients were diagnosed with BPD and underwent traditional medicaments without improvements in their conditions prior to allo-UC-MSC administration. Previous studies have shown the safety profile of MSCs in the prevention of BPD and acute lung injury in infants at risk [20,23, 31]. A recent study reported the safety of allogeneic administration of BM-MSCs in two severe and advanced BPD infants and suggested that MSC therapy should be conducted in early stages of the disease [32]. Because the respiratory outcomes of premature infants can vary widely and no specific early marker of BPD exists, the prediction of BPD development can be challenging. The earliest time at which BPD can be predicted is day 4 of life [33]. To confirm the diagnosis of BPD, subsequent studies found that BPD patterns typical of lung diseases emerge during the first 14 days of life. Moreover, during this period, several risk factors could affect disease severity, including late surfactant deficiency, sepsis, inflammation, and PDA 
[34, 35]. Furthermore, $50 \%$ of infants with pulmonary deterioration and nearly $70 \%$ of infants with early persistent pulmonary deterioration reportedly develop BPD [36]. Hence, it is important to determine the timing at which MSC therapy could be administered as a preventive treatment (intervention conducted within the first 14 postnatal days) or for BPD treatment (infants confirmed to have BPD).

In terms of study limitations, first and foremost, we can only report our safety data and cannot draw conclusions about either the efficacy or long-term safety of alloUC-MSCs for the treatment of BPD because only four patients were included and no control group was utilized. Based on the safety profiles of UC-MSCs in the treatment of BPD, it is important to perform a randomized, placebo-controlled phase 2 clinical trial with a larger cohort and a primary focus on safety and secondary outcomes, including respiratory, inflammatory, systemic, and MSC biological endpoints.

\section{Conclusions}

Our current study provides the evidence of the safety of the allogeneic administration of hUC-MSCs in patients with established BPD. The results also showed that BPD infants were weaned off of oxygen support with reduction of lung fibrosis and progression of lung function postadministration. A study with a larger cohort and a control group is needed to draw more accurate conclusions.

\section{Supplementary information}

Supplementary information accompanies this paper at https://doi. org/10.1186/s12967-020-02568-6.

Additional file 1: Table S1. Clinical data and detailed examinations of Patient 1.

Additional file 2: Table S2. Clinical data and detailed examinations of Patient 2.

Additional file 3: Table S3. Clinical data and detailed examinations of Patient 3.

Additional file 4: Table S4. Clinical data and detailed examinations of Patient 4. NI: No information, unable to obtain samples from patient.

Additional file 5. Figure S1: Hemodynamic and respiratory functions during $72 \mathrm{~h}$ of UC-MSC infusion. Mean ( \pm SEM) values of four patients for (a) heart rate (beats per minute), (b) temperature $\left({ }^{\circ} \mathrm{C}\right)$, and (c) arterial oxygen saturation as measured by pulse oximeter $\left(\mathrm{SpO}_{2} ; \%\right)$ at base line and every 3 hours from start of UC-MSC infusion up to $72 \mathrm{~h}$ post-transplantation.

\section{Abbreviations}

allo-UC-MSCs: Allogeneic administration of umbilical cord-derived mesenchymal stem/stromal cells; ABG: Arterial blood gas analysis; BE: Base excess; BPD: Bronchopulmonary dysplasia; BW: Body weight; $\mathrm{HCO}_{3}-$ : Bicarbonate; ITP: Idiopathic thrombocytopenia purpura; $\mathrm{PaCO}_{2}$ : Partial pressure of carbon dioxide; $\mathrm{PAH}$ : Pulmonary artery hypertension; $\mathrm{PaO}_{2}$ : Partial pressure of oxygen; PAP: Pulmonary artery pressure; PBW: Patient body weight; PEEP: Positive end-expiratory pressure; PIP: Peak inspiratory pressure; $\mathrm{SpO}_{2}$ : Saturated oxygen level in blood; UC-MSCs: Umbilical cord-derived mesenchymal stem/stromal cells.

\section{Acknowledgements}

The authors would like to thank all parents and patients involved in the study for their trust, understanding and willingness. This work was partially funded by the Vingroup Joint Stock Company (Scientific Investigation Program, grant number: ISC.19.15) and the Thien Tam Charity Organization. We also thank Michael Heke (Department of Biology, Stanford University, US) for his valuable comments on the manuscript.

\section{Authors' contributions}

LNT, TTHT, HTHB and DMH contributed equally to this work. LNT: Conception and design, administrative support, provision of study material or patients, data analysis and interpretation, manuscript writing, and final approval of manuscript. TTHT: provision of study material or patients, collection and/or assembly of data, data analysis and interpretation, manuscript writing, and approval of clinical assessment. HTHB: MSC processing and characterization, preparation of administration product, data analysis and interpretation. VTH: quality control of MSC product, flow cytometry analysis of MSC markers, data analysis and interpretation. ATTN: MSC processing and characterization. NTHT: Characterization and differentiation of UC-MSCS. KTN: Statistical and data analyses. DMH: administrative support, provision of study material or patients, data analysis and interpretation, manuscript writing, and final approval of manuscript. All authors read and approved the final manuscript.

\section{Funding}

This work was partially funded by the Vingroup Joint Stock Company (Scientific Investigation Program, grant number: ISC.19.15) and the Thien Tam Charity Organization.

\section{Availability of data and materials}

The authors declare that [the/all other] data supporting the findings of this study are available within the article [and its additional files].

\section{Ethics approval and consent to participate}

All clinical procedures, MSC administration and patient follow-up processes used in this study were approved by the Scientific and Ethics Committee of Vinmec International Hospital (approval number: 88/2019/QĐ-VMEC). Written consent was obtained from both the donor who donated the umbilical cord and from the patients' parents.

\section{Consent for publication}

Not applicable.

\section{Competing interests}

The authors have no competing interests to declare.

\section{Author details}

${ }^{1}$ Vinmec Research Institute of Stem Cell and Gene Technology, Vinmec Healthcare System, Hanoi, Vietnam. ${ }^{2}$ Vinmec International Hospital_-Times City, Vinmec Healthcare System, Hanoi, Vietnam. ${ }^{3}$ Vinmec Hi-Tech Center, Times City, Vinmec Healthcare System, Hanoi, Vietnam. ${ }^{4}$ Cellular Manufacturing Department, Vinmec Research Institute of Stem Cell and Gene Technology, 458 Minh Khai, Hai Ba Trung Ward, Hanoi, Vietnam.

Received: 2 July 2020 Accepted: 12 October 2020

Published online: 20 October 2020

\section{References}

1. Northway WH Jr, Rosan RC, Porter DY. Pulmonary disease following respirator therapy of hyaline-membrane disease. Bronchopulmonary dysplasia. N Engl J Med. 1967;276(7):357-68.

2. Higgins RD, Jobe AH, Koso-Thomas M, Bancalari E, Viscardi RM, Hartert TV, et al. Bronchopulmonary dysplasia: executive summary of a workshop. J Pediatr. 2018;197:300-8.

3. Jobe AH, Bancalari E. Bronchopulmonary dysplasia. Am J Respir Crit Care Med. 2001;163(7):1723-9. 
4. Kunjunju AM, Gopagondanahalli KR, Chan Y, Sehgal A. Bronchopulmonary dysplasia-associated pulmonary hypertension: clues from placental pathology. J Perinatol. 2017;37(12):1310-4.

5. Kalikkot Thekkeveedu R, Guaman MC, Shivanna B. Bronchopulmonary dysplasia: a review of pathogenesis and pathophysiology. Respir Med. 2017;132:170-7.

6. Jobe AH. Postnatal corticosteroids for bronchopulmonary dysplasia. Clin Perinatol. 2009;36(1):177-88.

7. Filippone M, Nardo D, Bonadies L, Salvadori S, Baraldi E. Update on Postnatal Corticosteroids to Prevent or Treat Bronchopulmonary Dysplasia. Am J Perinatol. 2019;36(S 02):S58-62.

8. Malaeb SN, Stonestreet BS. Steroids and injury to the developing brain: net harm or net benefit? Clin Perinatol. 2014:41(1):191-208.

9. Geary C, Caskey M, Fonseca R, Malloy M. Decreased incidence of bronchopulmonary dysplasia after early management changes, including surfactant and nasal continuous positive airway pressure treatment at delivery, lowered oxygen saturation goals, and early amino acid administration: a historical cohort study. Pediatrics. 2008;121(1):89-96.

10. Laughon M, Bose C, Moya F, Aschner J, Donn SM, Morabito C, et al. A pilot randomized, controlled trial of later treatment with a peptide-containing, synthetic surfactant for the prevention of bronchopulmonary dysplasia. Pediatrics. 2009;123(1):89-96.

11. Konig K, Guy KJ. Bronchopulmonary dysplasia in preterm infants managed with non-invasive ventilation or surfactant and a brief period of mechanical ventilation: a 6-year cohort study. J Matern Fetal Neonatal Med. 2014;27(6):608-11.

12. Gibson RL, Jackson JC, Twiggs GA, Redding GJ, Truog WE. Bronchopulmonary dysplasia. Survival after prolonged mechanical ventilation. Am J Dis Child. 1988;142(7):721-5.

13. Keszler M, Sant'Anna G. Mechanical ventilation and bronchopulmonary dysplasia. Clin Perinatol. 2015;42(4):781-96.

14. Michael Z, Spyropoulos F, Ghanta S, Christou H. Bronchopulmonary dysplasia: an update of current pharmacologic therapies and new approaches. Clin Med Insights Pediatr. 2018;12:1179556518817322.

15. O'Reilly M, Thebaud B. Animal models of bronchopulmonary dysplasia. The term rat models. Am J Physiol Lung Cell Mol Physiol. 2014;307(12):L948-58.

16. Reiter J, Drummond S, Sammour I, Huang J, Florea V, Dornas P, et al. Stromal derived factor-1 mediates the lung regenerative effects of mesenchymal stem cells in a rodent model of bronchopulmonary dysplasia. Respir Res. 2017;18(1):137.

17. Luan Y, Ding W, Ju ZY, Zhang ZH, Zhang X, Kong F. Bone marrow-derived mesenchymal stem cells protect against lung injury in a mouse model of bronchopulmonary dysplasia. Mol Med Rep. 2015;11(3):1945-50.

18. Tropea KA, Leder E, Aslam M, Lau AN, Raiser DM, Lee JH, et al. Bronchioalveolar stem cells increase after mesenchymal stromal cell treatment in a mouse model of bronchopulmonary dysplasia. Am J Physiol Lung Cell Mol Physiol. 2012;302(9):L829-37.

19. Chang YS, Oh W, Choi SJ, Sung DK, Kim SY, Choi EY, et al. Human umbilical cord blood-derived mesenchymal stem cells attenuate hyperoxiainduced lung injury in neonatal rats. Cell Transplant. 2009;18(8):869-86.

20. Chang YS, Ahn SY, Yoo HS, Sung SI, Choi SJ, Oh WI, et al. Mesenchymal stem cells for bronchopulmonary dysplasia: phase 1 dose-escalation clinical trial. J Pediatr. 2014;164(5):966-72.

21. Liem NT, Anh TL, Thai TTH, Anh BV. Bone marrow mononuclear cells transplantation in treatment of established bronchopulmonary dysplasia: a case report. Am J Case Rep. 2017;18:1090-4.

22. Ohlsson A, Shah PS. Paracetamol (acetaminophen) for patent ductus arteriosus in preterm or low birth weight infants. Cochrane Database Syst Rev. 2018:4:CD010061.
23. Ahn SY, Chang YS, Kim JH, Sung SI, Park WS. Two-year follow-up outcomes of premature infants enrolled in the phase I trial of mesenchymal stem cells transplantation for bronchopulmonary dysplasia. J Pediatr. 2017;185(49-54):e2.

24. Lim R, Malhotra A, Tan J, Chan ST, Lau S, Zhu D, et al. First-in-human administration of allogeneic amnion cells in premature infants with bronchopulmonary dysplasia: a safety study. Stem Cells Transl Med. 2018;7(9):628-35

25. Malhotra A, Lim R, Mockler JC, Wallace EM. Two-year outcomes of infants enrolled in the first-in-human study of amnion cells for bronchopulmonary dysplasia. Stem Cells Transl Med. 2020;9(3):289-94.

26. Pierro M, Ionescu L, Montemurro T, Vadivel A, Weissmann G, Oudit G, et al. Short-term, long-term and paracrine effect of human umbilical cordderived stem cells in lung injury prevention and repair in experimental bronchopulmonary dysplasia. Thorax. 2013;68(5):475-84.

27. Amable PR, Teixeira MV, Carias RB, Granjeiro JM, Borojevic R. Protein synthesis and secretion in human mesenchymal cells derived from bone marrow, adipose tissue and Wharton's jelly. Stem Cell Res Ther. 2014;5(2):53.

28. Simones AA, Beisang DJ, Panoskaltsis-Mortari A, Roberts KD. Mesenchymal stem cells in the pathogenesis and treatment of bronchopulmonary dysplasia: a clinical review. Pediatr Res. 2018;83(1-2):308-17.

29. Liu L, Mao Q, Chu S, Mounayar M, Abdi R, Fodor W, et al. Intranasal versus intraperitoneal delivery of human umbilical cord tissue-derived cultured mesenchymal stromal cells in a murine model of neonatal lung injury. Am J Pathol. 2014;184(12):3344-58.

30. Augustine S, Avey MT, Harrison B, Locke T, Ghannad M, Moher D, et al. Mesenchymal stromal cell therapy in bronchopulmonary dysplasia: systematic review and meta-analysis of preclinical studies. Stem Cells Transl Med. 2017;6(12):2079-93.

31. Chang YS, Choi SJ, Ahn SY, Sung DK, Sung SI, Yoo HS, et al. Timing of umbilical cord blood derived mesenchymal stem cells transplantation determines therapeutic efficacy in the neonatal hyperoxic lung injury. PLoS ONE. 2013;8(1):e52419.

32. Alvarez-Fuente M, Arruza L, Lopez-Ortego P, Moreno L, Ramirez-Orellana M, Labrandero C, et al. Off-label mesenchymal stromal cell treatment in two infants with severe bronchopulmonary dysplasia: clinical course and biomarkers profile. Cytotherapy. 2018;20(11):1337-44.

33. Ryan SW, Nycyk J, Shaw BN. Prediction of chronic neonatal lung disease on day 4 of life. Eur J Pediatr. 1996;155(8):668-71.

34. Merrill JD, Ballard RA, Cnaan A, Hibbs AM, Godinez RI, Godinez MH, et al. Dysfunction of pulmonary surfactant in chronically ventilated premature infants. Pediatr Res. 2004;56(6):918-26.

35. Laughon M, Bose C, Allred EN, O'Shea TM, Ehrenkranz RA, van Marter LJ, et al. Patterns of blood protein concentrations of ELGANs classified by three patterns of respiratory disease in the first 2 postnatal weeks. Pediatr Res. 2011;70(3):292-6.

36. Laughon M, Allred EN, Bose C, O'Shea TM, Van Marter L, Ehrenkranz RA, et al. Patterns of respiratory disease during the first 2 postnatal weeks in extremely premature infants. Pediatrics. 2009;123(4):1124-31.

\section{Publisher's Note}

Springer Nature remains neutral with regard to jurisdictional claims in published maps and institutional affiliations. 